\title{
Paranasal Sinus Schneiderian Papilloma
}

National Cancer Institute

\section{Source}

National Cancer Institute. Paranasal Sinus Schneiderian Papilloma. NCI Thesaurus. Code C6835.

A papilloma that arises from the ciliated respiratory mucosa that lines the paranasal sinuses. It is classified as inverted papilloma and oncocytic papilloma. 